\title{
VIRTUAL WATER POTENTIAL OF SELECTED COMMODITIES IN CO-OPERATION OF THE SLOVAK REPUBLIC WITH COUNTRIES OF THE WESTERN BALKANS
}

\author{
${ }^{\mathrm{a} O T I ́ L I A ~ Z O R K O ́ C I O V A ́, ~}{ }^{\mathrm{b}}$ DENISA ČIDEROVÁ, ${ }^{\mathrm{c} T A T I A N A}$ \\ SLUKA \\ University of Economics in Bratislava, Dolnozemská cesta 1, \\ 85235 Bratislava \\ email: ${ }^{a}$ otilia.zorkociova@euba.sk, ${ }^{b}$ denisa.ciderova@euba.sk, \\ 'tatiana.sluka@euba.sk
}

This paper was created within the research project of the Ministry of Education, Science, Research and Sport of the Slovak Republic VEGA No: 1/0420/19, VEGA 1/0777/20 and KEGA 003EU-4/2022

Abstract: Our paper rests on two fundamentals: firstly, the EU's initiative to deepe cooperation with and the prospect of its enlargement to the Western Balkans region; and, secondly, the urgency to address sustainable development issues in the ind, secondly, the tis pency to address sustainable development issues in the moto ppos in the rade-related chactentics bas the alternative RCA/RTA indexes designed to calculate a country's comparative advantage or disadvantage). In our paper, we analyse and evaluate selected commodities traded by the Slovak Republic and the Western Balkans countries in terms of the absolute/comparative advantage related to the national water footprints.

Keywords: Sustainable Development Goals (SDGs); international trade; absolute/comparative advantage; revealed (RCA)/relative (RTA) advantage measurements; water footprint in exports/imports; virtual water; Slovak Republic; Western Balkans.

\section{Introduction and Problem Formulation}

Before their accession to the European Union (EU), the Czech Republic and the Slovak Republic constituted a single contracting party of the „Declaration on Co-operation Between the Republic of Poland, the Czechoslovak Federal Republic and the Republic of Hungary on the Path for Advancing Towards European Integration“ (of 15 February 1991 - Visegrad Group); jointly they formed a customs union based on the „Agreement Establishing the Customs Union Between the Czech Republic and the Slovak Republic" (of 29 October 1992); and they became individual parties of the „Central European Free Trade Agreement" (of 21 December 1992 - CEFTA) with Central and East European Countries (CEECs). Čiderová and Kovačević (2015) indicate that as a matter of fact, the 1990s witnessing „centrifugal“ disintegration of a number of federal statehoods in Central and Eastern Europe marked parallel „centripetal“ attempts of now-independent successor states for (European) integration. Following the geopolitical commitment of the EU member states with regard to Central and Eastern Europe, the reality of "catching-up“ in geoeconomic terms fostered progressive participation of CEECs in the respective stages of economic integration framed by B. Balassa (in ascending order: free trade area; customs union; common market; economic union; total economic integration) in 1961.

Therefore, instead of the multilateral CEFTA free trade area and the bilateral customs union, the Czech Republic and the Slovak Republic have participated in the EU's joint customs union (with Andorra, Monaco, San Marino, and Turkey) and even the single European market as the EU customs union's upgrade, since their 2004 EU accession. After the 2007 and the 2013 EU enlargements to the East (Bulgaria, Romania) and West (Croatia) of the Balkan region, Turkey and the Western Balkans Six (Čiderová and Kovačević, 2015) now represent the so-called enlargement countries (Čiderová and Dionizi, 2015; Čiderová Fejesová - Kovačević, 2015; Čiderová and Kovačević, 2015; Zorkóciová and Petríková, 2018; Čiderová and Kovačević, 2019). Following the 2004, 2007 and 2013 EU enlargements, CEFTA did not cease to exist, but was transformed into CEFTA 2006 (of 19 December 2006) comprising (in alphabetical order): Albania; Bosnia and Herzegovina; Kosovo (UNSCR 1244/1999); Moldova; Montenegro; North Macedonia; Serbia. In this regard the 2021 Communication on EU Enlargement Policy (European Commission, 2021) states that in the area of trade policy "some progress was made in reducing Kosovo's trade deficit, but Kosovo has not yet ratified the CEFTA additional protocols on trade facilitation and trade in services". Overall, while in the Slovak Republic (SK) the share of exports (goods and services) as \% GDP or the share of imports (goods and services) as \% GDP lies in the interval between $90 \%$ of GDP and $100 \%$ of GDP, the same indicators of export perfomance and import intensity spread on a scale from $20 \%$ of GDP to $80 \%$ of GDP across the enlargement countries (in ascending order):

- in Turkey (TR) in the interval 20\% - 40\% GDP;

- in Kosovo (UNSCR 1244/1999 - XK) in the interval 20\% $60 \%$ GDP;

- in Albania (AL) in the interval 30\% - 50\% GDP;

- in Bosnia and Herzegovina (BA) in the interval $40 \%-60 \%$ GDP;

- in Montenegro (ME) in the interval 40\% - 70\% GDP;

- in Serbia (RS) in the interval 50\% - 70\% GDP.

- in North Macedonia (MK) in the interval 60\% - 80\% GDP (Fig. 1).

Fig. 1: Intervals of export performance and import intensity of the Slovak Republic in comparison with the so-called enlargement countries

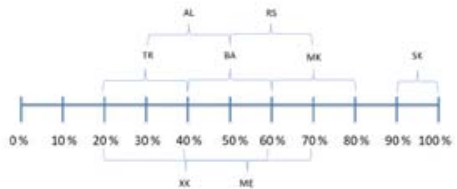

Source: European Commission (2020); European Commission (2021)

Fig. 1 implies the extent, to which disruptions in international trade may affect an economy. In the globalised world, participation in international trade goes hand in hand with participation in supply chains. International trade generates nearly 300 million jobs globally (corresponding to an estimate of USD 3,450 bil. in distributed wages annually) to produce goods in order to meet the demand in other countries - for illustration, 62 million jobs globally are generated to satisfy EU consumption (SDSN and IEEP, 2020)

On the one hand, according to the 2020 Europe Sustainable Development Report, most European countries contribute to considerable negative international spillovers in the form of $\mathrm{CO}_{2}$ emissions, biodiversity loss and water scarcity through trade. On the other hand, all countries would lose from a shift away from interconnected economies to a localised regime of production, as OECD reports (OECD, 2020), and in the EU alone 54 million jobs are generated to produce goods that will satisfy foreign consumption.

In this context, progress in terms of the United Nations 2030 Agenda represented by 17 Sustainable Development Goals (SDGs) necessitates to address negative impacts (Schmidt-Traub et al., 2019), including those accompanying unsustainable supply chains (SDG 12 Responsible consumption and production). "Europe must ensure coherence between its domestic and its international policies," was an appeal made by the 2019 Europe Sustainable Development Report (SDSN and IEEP, 2019). In response, the EU acknowledges the role of trade policy and sustainable supply chains for the accomplishment of the SDGs and the European Green Deal. In the words of the President of the European Commission U. von der Leyen: "Trade is not an end in itself. It is a means to deliver prosperity at home and to export our values across the world. I will ensure that every new agreement concluded will have a dedicated sustainabledevelopment chapter" (von der Leyen, 2019). Furthermore, the EU's "Farm to Fork" Strategy for a fair, healthy and environmentally friendly food system draws attention to the extent and significance of spillover effects in food supply chains. 
Amidst the COVID-19 crisis, having a negative impact on the SDGs (especially SDG 1 No poverty; SDG 2 Zero hunger; SDG 3 Good health and well-being; SDG 8 Decent work and economic growth) in Europe and globally, in the Council conclusions of 19 October 2020 on the "Farm to Fork" Strategy the Council of the EU welcomed the European Commission's intention to develop a contingency plan designed to ensure food supply and food security in times of crisis (Council of the European Union, 2021). In his keynote speech at the $2021 \mathrm{EU}$ Agricultural Outlook Conference J. Wojciechowski made an appeal: "Our emphasis is on sustainable agriculture, on agroecology, on practices that conserve soil, restrict $\mathrm{CO}_{2}$ emissions, and improve water management” (Wojciechowski, 2021).

Although SDG 6 (Clean water and sanitation) is specifically oriented on the issue of water management, as a matter of fact water availability/scarcity concerns all 17 SDGs. According to Hoekstra - Chapagain - van Oel (2019) water footprint assessment represents the study of freshwater use, scarcity and pollution in relation to consumption, production as well as trade patterns, and as such it is an interdisciplinary field. "By nature, the field is integrative, bringing together different disciplines and perspectives, for instance, natural sciences, policy studies, and geographical and supply-chain perspectives. It links water issues to food, energy, and climate and addresses issues of sustainability, efficiency, and equitability of resource use," they claim while emphasising that "indirect drivers of water problems, like incentives to produce water-intensive products in water-scarce regions for export” need to be taken into account, too.

Distance and borders, but also trade barriers and controversies in trade policy, environmental issues (e.g. water footprint), historical context or cultural trends (vegetarian/vegan lifestyle) play an important role in trade. Based on the comparison of selected commodities by Nagyová and Čiderová (2020) over the years 2012-2018 in the case of the Czech Republic and the Slovak Republic in the period before the outbreak of the COVID-19 pandemic, our option of countries covered corresponds with the planned enlargement of the $\mathrm{EU}$ to the Western Balkans region (Council of the European Union, 2021). As in the case of the Czech Republic and the Slovak Republic during the pre-accession period, we consider that CEFTA (now CEFTA 2006) continues to provide a framework assisting the Western Balkans region in the process of preparation for EU membership, too. Our focus on the Slovak Republic and five countries of the Western Balkans region is also facilitated by the Euro currency - by being the legal tender in the Slovak Republic and due to unilateral euroisation in Montenegro without the status of a legal tender (Čiderová and Dionizi, 2015).

In terms of the focus of the VEGA research project No. $1 / 0420 / 19$ the aim of our paper is to analyse trade-related characteristics based on the water footprint concept (complementary to the alternative RCA/RTA indexes designed to calculate a country's comparative advantage or disadvantage). In our paper we analyse and evaluate selected commodities traded by the Slovak Republic and the Western Balkans countries, so we will now proceed with application of the water footprint concept on the background of classical (political economy) concepts/theories of international trade and alternative revealed (RCA)/relative (RTA) advantage measurements in Part 2 Methodology and Part 3 Results. Then, Part 4 Conclusion will summarise our findings and outline their relevance.

\section{Methodology}

Zábojník - Čiderová - Krajčík (2020) list the following classical (political economy) concepts and theories of international trade:

- The concept of the invisible hand of the market (A. Smith) each country with a certain absolute advantage (lowest production costs) for the production of goods in international trade benefits from the specialisation in the production of such goods.
- The concept of foreign trade deregulation (D. Hume) achieving the benefits of international trade does not require a significant degree of state intervention in order to achieve a satisfactory balance and territorial structure.

- The concept of comparative costs (R. Torrens, D. Ricardo) involvement in international trade is effective and beneficial for the national economy, even if it has no absolute advantage. The prerequisite for the benefits of foreign trade are comparative costs (advantages).

"Measuring comparative advantages is not easy at all in practice,“ Zábojník - Čiderová - Krajčík (2020) argue, pointing out that a method that measures the comparative advantage based on ex-post international trade data in the form of the most common and well-known index (the Revealed Comparative Advantage - RCA index) is used.

According to UNCTADSTAT, the "Revealed Comparative Advantage is based on Ricardian trade theory, which posits that patterns of trade among countries are governed by their relative differences in productivity"; however, it should be noted that applied national measures affecting competitiveness such as tariffs, non-tariff measures, subsidies and others are not considered in the RCA metric even though the RCA metric can provide a general indication of a country's competitive export strengths, UNCTADSTAT highlights.

A country with a revealed comparative advantage $(\mathrm{RCA}>1)$ for product $i$ is interpreted as a competitive producer and exporter of that product relative to a country producing and exporting the same product at or below the world average.

That is,

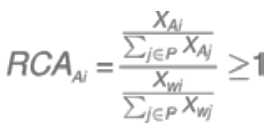

Where

$P$ is the set of all products (with $i \in P$ ),

$\mathrm{XAi}$ is the country A's exports of product $\mathrm{i}$,

Xwi is the worlds's exports of product $i$,

$\Sigma \mathrm{j} \in \mathrm{PXAj}$ is the country A's total exports (of all products $\mathrm{j}$ in $\mathrm{P}$ ), and

$\Sigma \mathrm{j} \in \mathrm{PXwj}$ is the world's total exports (of all products $\mathrm{j}$ in $\mathrm{P}$ ).

Bojnec and Fertő (2012) cite Vollrath (1991) who outlined an alternative specification of the revealed comparative advantage titled as the Relative Trade Advantage (RTA) accounting for exports as well as imports and calculated as follows:

Relative Trade Advantage $=$ Revealed Comparative Export Advantage - Relative Import Penetration Advantage, i.e.

$\mathrm{RTA}=\mathrm{RXA}-\mathrm{RMA}$

When

$\mathrm{RXA}=(\mathrm{Xij} / \mathrm{Xit}) /(\mathrm{Xnj} / \mathrm{Xnt})$, i.e.

in the Revealed Comparative Export Advantage indicator $\mathrm{X}$ represents exports, $i$ is a country, $j$ is a commodity, $t$ is a set of commodities, and $\mathrm{n}$ is a set of countries;

RMA = (Mij / Mit) / (Mnj / Mnt)

in the Relative Import Penetration Advantage indicator $\mathrm{M}$ represents imports, $i$ is a country, $j$ is a commodity, $t$ is a set of commodities, and $n$ is a set of countries.

Then,

RTA $=[($ Xij / Xit $) /(X n j /$ Xnt $)]-[($ Mij / Mit) / (Mnj / Mnt) $]$. 
Bojnec and Fertő (2012) classify the RTA index in three categories:

- RTA $>0$ relates to product groups with a relative comparative trade advantage;

- $\quad$ RTA $=0$ relates to product groups in a breakeven point without relative comparative trade advantage or relative comparative trade disadvantage;

- RTA $<0$ relates to product groups with a relative comparative trade disadvantage.

Both A. Smith and D. Ricardo would appeal to policymakers "to look at the health of the domestic economy and not focus solely on the trade position. [...] Aiming for a trade surplus without examining what needs to be done in the domestic economy to make exports more desirable to the rest of the world would have struck Ricardo as the wrong way to go about it," Yueh (2019) argues. In his paper titled "Invisible Hand or Ecological Footprint? Comparing Social Versus Environmental Impacts of Recent Economic Growth" Mikkelson (2019) also suggests that public policy should shift toward enhancement of individual and social well-being in ways more direct and effective, and less ecologically damaging, than reliance on overall growth in gross domestic product (see also Zorkóciová and Palušková, 2019).

Mekonnen and Hoekstra (2011) point out that governments have traditionally adopted a purely national perspective when considering the match between national water supplies and national water demands. In line with such a consideration, a mismatch between national water supplies and national water demands might focus on maximising the first while minimising the latter. Still, the global dimension of water demand patterns tends to be abstracted from. "Since production processes in a global economy can shift from one place to another, water demands can be met outside the boundaries of a nation through the import of commodities," Mekonnen and Hoekstra (2011) argue. In their words, "[a]ll countries trade water-intensive commodities, but few governments explicitly consider options to save water through import of water-intensive products or to make use of relative water abundance to produce water-intensive commodities for export”.

In terms of its scope, the water footprint concept "is integrative by nature by its applicability at different levels (local to global) and along supply chains (from investment and production to processing, sales, and consumption)" (Hoekstra - Chapagain van Oel, 2019). Water footprint defined as the volume of water consumed in the production of goods or services represents the combination of the following blue, green and grey elements:

- blue water footprint relates to the consumption of the socalled blue water resources such as surface and ground water;

- green water footprint symbolises the consumption of rainwater as the so-called green water, which is significant especially in the case of crop production;

- grey water footprint is associated with the volume of freshwater needed to assimilate the load of pollutants in order to ensure compliance with the ambient water quality standards in place.

According to Hoekstra (2003), since the introduction of the water footprint concept at the dawn of the millennium, the endeavour to quantify and map the so-called national water footprints has represented an evolving field of study.

To calculate the water footprint of national consumption particularly for agricultural commodities, all agricultural products consumed by the population of the respective country are multiplied by the corresponding product water footprint as follows:

$$
\left.W F_{\text {cons, indir }} \text { (agricultural commodities }\right)=\sum_{p}\left(C[p] \times W F_{p r o d}^{*}[p]\right)
$$

Where

$C[p]$ is consumption of agricultural product $p$ by consumers of the respective country (t/yr),

$W F^{*}{ }_{\text {prod }}[p]$ is the water footprint of the product $\left(\mathrm{m}^{3} / \mathrm{t}\right)$.

Then,

the average water footprint of a product $p$ consumed in the respective country is as follows:

$$
W F_{\text {prod }}^{*}[p]=\frac{P[p] \times W F_{\text {prod }}[p]+\sum_{n_{e}}\left(T_{i}\left[n_{e}, p\right] \times W F_{\text {prod }}\left[n_{e}, p\right]\right)}{P[p]+\sum_{n_{e}} T_{i}\left[n_{e}, p\right]}
$$

Where

$P[p]$ is the production quantity of a product $p$ in the respective country,

$T_{i}\left[n_{e}, p\right]$ is the imported quantity of product $p$ from exporting country $n_{e}$,

$W F_{\text {prod }}[p]$ is the water footprint of product $p$ when produced in the country considered,

$W F_{\text {prod }}\left[n_{e}, p\right]$ is the water footprint of product $p$ as in the exporting country $n_{e}$.

Subsequently, it is assumed that "the total consumption volume originates from domestic production and imports according to their relative volumes" (Mekonnen and Hoekstra, 2011).

As an indicator that is geographically explicit, the water footprint refers to the volume of water consumption just like the respective location; thus, we can consider the global average water footprint, or a national water footprint.

In their study oriented on the Czech Republic and the Slovak Republic, Nagyová and Čiderová (2020) focused on foreign trade of the two republics as well as their bilateral trade between 2012 and 2018 in the case of ten selected commodities: wheat; barley; maize; paddy rice; soyabeans; beef; pork; sheep (mutton+goat); sugar beet; sugar cane.

In this paper we will steer our attention in the framework of the VEGA research project No. 1/0420/19 to the Slovak Republic and five countries of the Western Balkans (in alphabetical order: Albania; Bosnia and Herzegovina; Montenegro; North Macedonia; Serbia). Furthermore, out of ten commodities examined by Nagyová and Čiderová (2020), we will streamline our focus on four commodities: wheat, maize, beef and pork. There is a reference to all of these commodities in the masterpiece "An Inquiry into the Nature and Causes of the Wealth of Nations" by A. Smith (1776) and the selection of these commodities was motivated by their substitutability (wheat and maize as substitutes; beef and pork as substitutes).

First and foremost, we will compare the global average water footprint with national water footprints of the respective countries that correspond with the selected commodities. Tab. 1 indicates the global average water footprint $(1 / \mathrm{kg})$ together with average water footprint $(\mathrm{l} / \mathrm{kg})$ in the Slovak Republic and in the countries of the Western Balkans considered (Serbia; Bosnia and Herzegovina; Montenegro; North Macedonia; Albania) for wheat, maize, beef and pork. 
Tab. 1: Global average water footprint $(\mathrm{l} / \mathrm{kg})$ and national average water footprint $(1 / \mathrm{kg})$ in the Slovak Republic and five countries of the Western Balkans for selected commodities

\begin{tabular}{|c|c|c|c|c|}
\hline $\begin{array}{c}\text { Global } \\
\text { average water } \\
\text { footprint, l/kg }\end{array}$ & 1,827 & 1,222 & 15,415 & 5,988 \\
\hline \multicolumn{5}{|c|}{ Commodities } \\
\hline $\begin{array}{c}\text { National } \\
\text { average water } \\
\text { footprint, l/kg }\end{array}$ & WHEAT & MAIZE & BEEF & PORK \\
\hline SK & $\mathbf{1 , 0 9 7}$ & $\mathbf{9 3 2}$ & $\mathbf{8 , 9 2 7}$ & $\mathbf{4 , 2 9 0}$ \\
\hline RS & 1,486 & 985 & 14,180 & 4,789 \\
\hline BA & 1,632 & 1,036 & 15,003 & 5,408 \\
\hline ME & 1,486 & 985 & 14,180 & 4,789 \\
\hline MK & 1,521 & 958 & 14,125 & 4,951 \\
\hline AL & 1,556 & 1,199 & 14,693 & 4,841 \\
\hline
\end{tabular}

Source: National water footprint accounts.

All countries covered in Tab. 1 demonstrate their level of average water footprint $(\mathrm{l} / \mathrm{kg})$ for the commodities of our choice below the respective global average water footprint values $(\mathrm{l} / \mathrm{kg})$. When taken from the country perspective, individual average water footprints range from $932 \mathrm{l} / \mathrm{kg}$ to $8,927 \mathrm{l} / \mathrm{kg}$ (SK); from $958 \mathrm{l} / \mathrm{kg}$ to $14,125 \mathrm{l} / \mathrm{kg}$ (MK); from $985 \mathrm{l} / \mathrm{kg}$ to $14,180 \mathrm{l} / \mathrm{kg}$ (RS \& ME); from $1,036 \mathrm{l} / \mathrm{kg}$ to $15,003 \mathrm{l} / \mathrm{kg}$ (BA); from $1,199 \mathrm{l} / \mathrm{kg}$ to $14,693 \mathrm{l} / \mathrm{kg}(\mathrm{AL})$. Across commodities, the national average water footprints spread in an interval from $932 \mathrm{l} / \mathrm{kg}$ to $1,199 \mathrm{l} / \mathrm{kg}$ (maize); from 1,097 l/kg to $1,632 \mathrm{l} / \mathrm{kg}$ (wheat); from $4,290 \mathrm{l} / \mathrm{kg}$ to $5,408 \mathrm{l} / \mathrm{kg}$ (pork); from $8,927 \mathrm{l} / \mathrm{kg}$ to $15,003 \mathrm{l} / \mathrm{kg}$ (beef)

\section{Results}

Data on foreign trade (with goods) of individual countries as well as bilateral trade were taken from the International Trade Centre TradeMap Database (2021), which covers data disaggregated both by partner countries and products. Our analysis documents data for the period 2012-2019, which on the one hand corresponds with the release of data on water footprints, and on the other hand it covers international trade and related international virtual water (Hoekstra, 2013) flows before the outbreak of the COVID-19 pandemic (having significant global impact on international trade) in Europe.

Tab. 2: Bilateral trade balance (in foreign trade with goods) of the Slovak Republic with five countries of the Western Balkans (2012-2019, in thousand Euro)

\begin{tabular}{|c|c|c|c|c|c|}
\hline Balance (EX-IM) & $\begin{array}{c}\text { SK- } \\
\text { RS }\end{array}$ & $\begin{array}{c}\text { SK- } \\
\text { BA }\end{array}$ & $\begin{array}{c}\text { SK- } \\
\text { ME }\end{array}$ & $\begin{array}{c}\text { SK- } \\
\text { MK }\end{array}$ & $\begin{array}{c}\text { SK- } \\
\text { AL }\end{array}$ \\
\hline 2012 & 141,252 & 27,294 & 12,535 & $-22,040$ & 20,801 \\
\hline 2013 & 150,814 & 31,455 & 31,583 & $-19,564$ & 37,969 \\
\hline 2014 & 78,076 & 18,384 & 35,138 & $-11,737$ & 33,399 \\
\hline 2015 & 53,933 & 22,760 & 29,057 & $-11,498$ & 35,631 \\
\hline 2016 & 15,312 & 15,852 & 20,326 & 11,533 & 25,878 \\
\hline 2017 & 6,356 & 27,168 & 15,674 & 30,253 & 28,402 \\
\hline 2018 & $-11,097$ & 23,608 & 18,341 & 6,069 & 17,379 \\
\hline 2019 & $-57,654$ & 41,560 & 24,108 & 12,793 & 22,331 \\
\hline
\end{tabular}

Source: ITC TradeMap Database (2021)

In terms of bilateral trade balance (in foreign trade with goods) of the Slovak Republic with five countries of the Western Balkans between 2012-2019 (Tab. 2) the Slovak Republic recently (2018-2019) registered a shift from a positive trade balance to a negative trade balance in bilateral trade with Serbia. With Bosnia and Herzegovina, Montenegro and Albania the trade balance of the Slovak Republic continues to be positive; in bilateral trade of Slovakia with North Macedonia an originally negative trade balance turned into a positive one. Data on foreign trade (with goods) of individual countries as well as bilateral trade taken from the International Trade Centre TradeMap Database (2021) show non-existence of bilateral trade (SK-RS; SK-BA; SK-ME; SK-MK; SK-AL) with the selected commodities despite their national average water footprints being below the global average water footprint demonstrated above. This is why figures on trade balance will now be followed by the water footprint balance for the Slovak Republic as well as for the respective Western Balkans countries covered in the case of selected commodities internationally traded between 2012-2019. As international virtual water flows result from multiplying the volume of traded commodity by the corresponding national average water footprint, we will next calculate the water footprint balance for wheat, maize, beef and pork in Tab. $3-8$ for each country separately.

Tab. 3: Water footprint balance in the Slovak Republic for selected commodities internationally traded between 2012-2019 (in thousand $\mathrm{m}^{3} / \mathrm{t}$ )

\begin{tabular}{|c|c|c|c|c|}
\hline WF $(\mathrm{l} / \mathrm{kg})$ & 1,097 & 932 & 8,927 & 4,290 \\
\hline \multicolumn{5}{|c|}{ Water footprint balance } \\
\hline SK & WHEAT & MAIZE & BEEF & PORK \\
\hline 2012 & 104,698 & 248,329 & $-35,190$ & $-251,016$ \\
\hline 2013 & 287,656 & 216,640 & $-61,802$ & $-390,948$ \\
\hline 2014 & 331,516 & 285,098 & $-28,897$ & $-334,049$ \\
\hline 2015 & 488,008 & 332,471 & $-52,669$ & $-363,217$ \\
\hline 2016 & 643,629 & 193,714 & $-66,417$ & $-489,776$ \\
\hline 2017 & 516,684 & 400,205 & $-85,539$ & $-503,633$ \\
\hline 2018 & 416,688 & 146,933 & $-83,048$ & $-479,099$ \\
\hline 2019 & 459,278 & 266,759 & $-72,166$ & $-441,128$ \\
\hline
\end{tabular}

Source: ITC TradeMap Database (2021)

Tab. 4: Water footprint balance in Serbia for selected commodities internationally traded between 2012-2019 (in thousand $\mathrm{m}^{3} / \mathrm{t}$ )

\begin{tabular}{|c|c|c|c|c|}
\hline WF $(1 / k g)$ & 1,486 & 985 & 14,180 & 4,789 \\
\hline \multicolumn{5}{|c|}{ Water footprint balance } \\
\hline RS & WHEAT & MAIZE & BEEF & PORK \\
\hline 2012 & 95,254 & $2,086,373$ & 21,242 & $-32,594$ \\
\hline 2013 & 153,259 & 764,855 & 18,590 & $-42,732$ \\
\hline 2014 & 58,682 & $2,335,527$ & 15,655 & 4,559 \\
\hline 2015 & 53,472 & $2,058,425$ & 6,126 & $-34,098$ \\
\hline 2016 & 65,365 & $2,025,469$ & 17,059 & $-34,969$ \\
\hline 2017 & 84,258 & $1,563,300$ & 41,973 & $-63,914$ \\
\hline 2018 & $1,264,378$ & $1,171,521$ & 64,562 & $-110,310$ \\
\hline 2019 & 24,220 & $2,944,435$ & 14,109 & $-88,774$ \\
\hline
\end{tabular}

Source: ITC TradeMap Database (2021)

Net export of wheat and maize in the case of Slovakia (Tab. 3) leads to water consumption, ceteris paribus. In contrast, net import of beef and pork to Slovakia results in water savings, ceteris paribus. 
In the case of Serbia (Tab. 4) net export of wheat, maize and beef leads to water consumption, ceteris paribus. On the contrary, net import of pork to Serbia results in water savings, ceteris paribus

Tab. 5: Water footprint balance in Bosnia and Herzegovina for selected commodities internationally traded between 2012-2019 (in thousand $\mathrm{m}^{3} / \mathrm{t}$ )

\begin{tabular}{|c|c|c|c|c|}
\hline WF $(\mathrm{l} / \mathrm{kg})$ & 1,632 & 1,036 & 15,003 & 5,408 \\
\hline \multicolumn{5}{|c|}{ Water footprint balance } \\
\hline BA & WHEAT & MAIZE & BEEF & PORK \\
\hline 2012 & -286 & $-134,651$ & $-113,018$ & $-26,418$ \\
\hline 2013 & 640 & $-228,911$ & $-230,386$ & $-45,535$ \\
\hline 2014 & -165 & $-201,044$ & $-356,096$ & $-63,685$ \\
\hline 2015 & $-23,894$ & $-216,063$ & $-353,066$ & $-75,701$ \\
\hline 2016 & $-29,115$ & $-264,680$ & $-384,497$ & $-71,332$ \\
\hline 2017 & $-26,750$ & $-214,887$ & $-329,841$ & $-72,851$ \\
\hline 2018 & $-26,070$ & $-225,499$ & $-384,182$ & $-83,527$ \\
\hline 2019 & $-7,695$ & $-184,716$ & $-473,210$ & $-79,362$ \\
\hline
\end{tabular}

Source: ITC TradeMap Database (2021)

Overall, Bosnia and Herzegovina (Tab. 5) is in the position of a net importer of wheat, maize, beef and pork, which might be interpreted as a tradeoff between conservation of water resources and export earnings, ceteris paribus.

Tab. 6: Water footprint balance in Montenegro for selected commodities internationally traded between 2012-2019 (in thousand $\mathrm{m}^{3} / \mathrm{t}$ )

\begin{tabular}{|c|c|c|c|c|}
\hline WF (l/kg) & 1,486 & 985 & 14,180 & 4,789 \\
\hline \multicolumn{5}{|c|}{ Water footprint balance } \\
\hline 2012 & $-46,825$ & $-8,089$ & $-34,401$ & $-91,101$ \\
\hline 2013 & $-44,767$ & $-6,389$ & $-40,300$ & $-96,450$ \\
\hline 2014 & $-59,284$ & $-9,840$ & $-49,786$ & $-102,020$ \\
\hline 2015 & $-60,681$ & $-13,144$ & $-46,241$ & $-99,262$ \\
\hline 2016 & $-41,728$ & $-18,864$ & $-57,500$ & $-106,249$ \\
\hline 2017 & $-2,976$ & $-21,673$ & $-60,308$ & $-99,961$ \\
\hline 2018 & $-1,639$ & $-26,839$ & $-63,952$ & $-111,718$ \\
\hline 2019 & $-4,225$ & $-30,585$ & $-59,811$ & $-98,898$ \\
\hline
\end{tabular}

Similarly, Montenegro's position (Tab. 6) of a net importer of wheat, maize, beef and pork might also be interpreted as a tradeoff between export earnings and conservation of water resources, ceteris paribus.

The case of North Macedonia (Tab. 7) as a net exporter of wheat implies water consumption, ceteris paribus. Conversely, net imports of maize, beef and pork registered in North Macedonia suggest water savings, ceteris paribus.
Tab. 7: Water footprint balance in North Macedonia for selected commodities internationally traded between 2012-2019 (in thousand $\mathrm{m}^{3} / \mathrm{t}$ )

\begin{tabular}{|c|c|c|c|c|}
\hline WF (l/kg) & 1,521 & 958 & 14,125 & 4,951 \\
\hline \multicolumn{5}{|c|}{ Water footprint balance } \\
\hline MK & WHEAT & MAIZE & BEEF & PORK \\
\hline 2012 & -415 & $-60,074$ & $-108,042$ & $-54,639$ \\
\hline 2013 & 0 & $-46,722$ & $-99,242$ & $-60,219$ \\
\hline 2014 & 1,036 & $-44,834$ & $-100,810$ & $-52,956$ \\
\hline 2015 & 1,831 & $-52,314$ & $-102,406$ & $-53,624$ \\
\hline 2016 & 3,393 & $-48,282$ & $-102,053$ & $-58,580$ \\
\hline 2017 & 17,893 & $-54,111$ & $-99,920$ & $-58,843$ \\
\hline 2018 & 16,296 & $-32,022$ & $-103,974$ & $-67,200$ \\
\hline 2019 & 3,206 & $-12,038$ & $-113,283$ & $-59,318$ \\
\hline
\end{tabular}

Source: ITC TradeMap Database (2021)

Tab. 8: Water footprint balance in Albania for selected commodities internationally traded between 2012-2019 (in thousand $\mathrm{m}^{3} / \mathrm{t}$ )

\begin{tabular}{|c|c|c|c|c|}
\hline WF $(\mathrm{l} / \mathrm{kg})$ & 1,556 & 1,199 & 14,693 & 4,841 \\
\hline \multicolumn{5}{|c|}{ Water footprint balance } \\
\hline AL & WHEAT & MAIZE & BEEF & PORK \\
\hline 2012 & $-14,292$ & $-55,859$ & -103 & $-52,772$ \\
\hline 2013 & $-65,166$ & $-76,385$ & -29 & $-51,876$ \\
\hline 2014 & $-4,242$ & $-61,187$ & 0 & $-24,302$ \\
\hline 2015 & $-2,497$ & $-76,312$ & -44 & $-28,305$ \\
\hline 2016 & $-4,136$ & $-86,782$ & -44 & $-27,986$ \\
\hline 2017 & $-2,191$ & $-78,148$ & 0 & 0 \\
\hline 2018 & $-3,307$ & $-101,046$ & 0 & $-21,407$ \\
\hline 2019 & -601 & $-106,873$ & -59 & 0 \\
\hline
\end{tabular}

All in all, the case of Albania (Tab. 8) being in the position of a net importer of wheat, maize, beef and pork might be interpreted as the case of tradeoff between conservation of water resources and export earnings, ceteris paribus, too.

\section{Conclusion}

In this paper we focused our attention in the framework of the VEGA research project No. 1/0420/19 on the Slovak Republic and five countries of the Western Balkans (in alphabetical order: Albania; Bosnia and Herzegovina; Montenegro; North Macedonia; Serbia) with the aim analyse trade-related characteristics based on the water footprint concept, i.e. we analyse and evaluate selected commodities traded by the Slovak Republic and the Western Balkans countries in terms of the absolute/comparative advantage related to the national water footprints.

Our option of countries covered corresponds with the planned enlargement of the EU to the Western Balkans region - and just like in the case of the Slovak Republic during the pre-accession period, CEFTA (now CEFTA 2006) was meant to help the candidate countries and potential candidates to prepare for EU membership. 
Data on foreign trade (with goods) of individual countries as well as bilateral trade were taken from the International Trade Centre TradeMap Database (2021) covering data disaggregated both by partner countries and products. Our analysis documented data for the period 2012-2019, which on the one hand corresponds with the release of data on water footprints, and on the other hand it covers international trade and related international virtual water flows before the outbreak of the COVID-19 pandemic in Europe. Out of ten commodities examined by Nagyová and Čiderová (2020), we streamlined our focus on four commodities: wheat, maize, beef and pork. The selection of these commodities was motivated by their substitutability (wheat and maize as substitutes; beef and pork as substitutes).

On the one hand, the Slovak Republic has had an overall negative trade balance with Serbia in recent years; on the other hand, the Slovak Republic overall registers an individual positive trade balance with Albania, Bosnia and Herzegovina, and Montenegro (in recent years also with North Macedonia). International virtual water flows resulting from trade with wheat, maize, beef and pork document total positive water footprint balance (i.e. export earnings and water consumption) in these cases:

- $\quad$ net export of wheat, maize and beef in the case of Serbia;

- net export of wheat and maize in the case of Slovakia;

- net export of wheat in the case of North Macedonia;

and total negative water footprint balance (i.e. water savings and no export earnings) in these cases:

- net import of wheat, maize, beef and pork in the case of Albania, Bosnia and Herzegovina, and Montenegro;

- net import of maize, beef and pork in the case of North Macedonia;

- net import of beef and pork in the case of Slovakia;

- net import of pork in the case of Serbia.

Ceteris paribus, in Serbia as one of the largest markets in the Western Balkans region (Zorkóciová and Petríková, 2018), there is further potential in individual bilateral trade (RS-BA; RS-ME; RS-AL) with maize. Even though Serbia could intensify its exports of maize to North Macedonia as well, adherence to the water footprint concept would rather suggest exports of maize from the Slovak Republic (based on the national water footprint of $932 \mathrm{l} / \mathrm{kg}$ ) to North Macedonia (based on the national water footprint of $958 \mathrm{l} / \mathrm{kg}$ )

Additionally, as the 2012-2019 data documented non-existence of bilateral trade (SK-BA; SK-ME; SK-MK; SK-AL) of the Slovak Republic with the selected commodities despite their national average water footprints being below the global average water footprint, in terms of the absolute/comparative advantage concept there is, ceteris paribus, potential for trade creation in bilateral trade of the Slovak Republic:

- i.e. in SK-BA bilateral trade with wheat on the basis of the respective national water footprints for the Slovak Republic $(1,097 \mathrm{l} / \mathrm{kg})$ and for Bosnia and Herzegovina (1,632 l/kg);

- i.e. in SK-AL bilateral trade with wheat on the basis of the respective national water footprints for the Slovak Republic $(1,097 \mathrm{l} / \mathrm{kg})$ and for Albania (1,556 l/kg);

- i.e. in SK-ME bilateral trade with wheat on the basis of the respective national water footprints for the Slovak Republic $(1,097 \mathrm{l} / \mathrm{kg})$ and for Montenegro (1,486 l/kg).

Subject to data availability, future research might incorporate Kosovo (UNSCR 1244/1999) as another enlargement country in the Western Balkans region (Čiderová and Dionizi, 2015; European Commission, 2021), too.

\section{Literature:}

1. „Agreement Establishing the Customs Union Between the Czech Republic and the Slovak Republic" of 29 October 1992.
2. „Agreement on Amendment of and Accession to the Central European Free Trade Agreement" of 19 December 2006 CEFTA 2006.

3. Balassa, B.: The Theory of Economic Integration. London: George Allen \& Unwin, 1961. ISBN 978-0-415-67910-7.

4. Bojnec, Š., Fertő, I.: Complementarities of trade advantage and trade competitiveness measures. In: Applied Economics. February 2012. https://doi.org/10.1080/00036846.2010.508725

5. „Central European Free Trade Agreement“ of 21 December 1992.

6. Council of the European Union: Council conclusions on the contingency plan for ensuring food supply and food security in times of crisis. Brussels, 13 December 2021.

7. Council of the European Union: Enlargement and Stabilisation and Association Process - Council Conclusions. Brussels, 14 December 2021.

8. Čiderová, D., Dionizi, B.: EU accession experience and perspectives: the case of Slovakia and Kosovo (UNSCR 1244/1999). European perspectives of the Western Balkans countries I, pp. 65-102. Prishtina: AAB College, 2015 / Terem Peter; Obadi Saleh Mothana. ISBN 978-9951-494-52-6.

9. Čiderová, D., Fejesová, B., Kovačević, D.: European Union enlargement to the Western Balkans applied to the Acapulco typology of agenda-setting: focus on Albania, Bosnia and Herzegovina and Kosovo (under UNSCR 1244/1999) revisited. In SGEM 2015: International multidisciplinary scientific conference on social sciences and arts, 26 august - 1 september, 2015, Albena, Bulgaria, Book 2, vol. 1, pp. 93-100. Sofia: STEF92 Technology, 2015; SGEM 2015 International multidisciplinary scientific conference on social sciences and arts. ISBN 978-619-7105-46-9.

10. Čiderová, D., Fejesová, B., Kovačević, D.: European Union enlargement to the Western Balkans applied to the Acapulco typology of agenda-setting: focus on Montenegro, Serbia and FYROM revisited. In SGEM 2015: International multidisciplinary scientific conference on social sciences and arts, 26 august - 1 september, 2015, Albena, Bulgaria, Book 2, vol. 1, pp. 101-109. Sofia: STEF92 Technology, 2015; SGEM 2015 International multidisciplinary scientific conference on social sciences and arts. ISBN 978-619-7105-46-9.

11. Čiderová, D., Kovačević, D.: EU Accession Experience and Perspectives: The Case of Slovakia and Bosnia and Herzegovina. In ERAZ 2019: Knowledge Based Sustainable Development: Conference Proceedings of the Fifth International Scientific Conference, May 23, 2019, Budapest, Hungary. Belgrade: Association of Economists and Managers of the Balkans, 2019; ERAZ 2019: Knowledge Based Sustainable Development International Scientific Conference. ISBN 978-8680194-20-2, pp. 245-266 online.

http://dx.doi.org/10.31410/ERAZ.2019.245

12. Čiderová, D., Kovačević, D.: Slovakia and Croatia as "new" member states of the EU: experiences. The European Union 10 years after its biggest enlargement: a "new" EU member states' perspective, pp. 429-445. Poznań: Poznań University of Economics Press, 2015 / Budković Hrvoje; Czachór Zbigniew. ISBN 978-83-7417-843-3

13. Čiderová, D., Kovačević, D.: Slovakia and Croatia as "new" member states of the EU: perspectives. The European Union 10 years after its biggest enlargement: a "new" EU member states' perspective, pp. 446-464. Poznań: Poznań University of Economics Press, 2015 / Budković Hrvoje; Czachór Zbigniew. ISBN 978-83-7417-843-3

14. Čiderová, D., Kovačević, D.: Visegrad meets Visegrad: the Visegrad Four and the Western Balkans Six. In: European Scientific Journal. 2015. Vol. 1(October), pp. 176-202 online. Azores: European Scientific Institute and University of the Azores, 2015. ISSN 1857-7431.

15. „Declaration on Co-operation Between the Republic of Poland, the Czechoslovak Federal Republic and the Republic of Hungary on the Path for Advancing Towards European Integration " of 15 February 1991.

16. European Commission: 2021 Communication on EU Enlargement Policy. Strasbourg, 19 October 2021.

17. European Commission: European Economic Forecast. Autumn 2020. 2020.

Retrieved from https://ec.europa.eu/info/business-economy-euro/ 
economic-performance-and-forecasts/economicforecasts/autumn-2020-economic-forecast_en

18. Hoekstra, A. Y.: Virtual water trade: Proceedings of the International Expert Meeting on Virtual Water Trade. Delft: UNESCO-IHE, 2013.

19. Hoekstra, A. Y., Chapagain, A. K., van Oel, P. R.: Progress in Water Footprint Assessment: Towards Collective Action in Water Governance. In Water, 2019, 11, https://doi.org/10.3390/w11051070

20. Mekonnen, M., Hoekstra, A. Y.: National water footprint accounts. Vol 1. Delft: UNESCO-IHE, 2011. 50 p.

21. Mekonnen, M., Hoekstra, A. Y.: National water footprint accounts. Vol 2. Delft: UNESCO-IHE, 2011. 94 p.

22. Mekonnen, M., Hoekstra, A. Y.: The green, blue and grey water footprint of crops and derived crop products. Vol 1. Delft: UNESCO-IHE, 2010. $42 \mathrm{p}$

23. Mekonnen, M., Hoekstra, A. Y.: The green, blue and grey water footprint of crops and derived crop products. Vol 2. Delft: UNESCO-IHE, 2010. 1196 p.

24. Mikkelson, M. G.: Invisible Hand or Ecological Footprint? Comparing Social Versus Environmental Impacts of Recent Economic Growth. In: SAGE. 2019. Vol. 1(11). https://doi.org/10.1177/1086026619885111

25. Nagyová, A., Čiderová, D.: Water footprint and the revisited competitiveness perspective of the Czech Republic and the Slovak Republic in terms of bilateral trade. In DOKBAT 2020 16th Annual International Bata Conference for Ph.D. Students and Young Researchers (Vol. 16). Zlín: Tomas Bata University in Zlín, Faculty of Management and Economics. Retrieved from http://dokbat.utb.cz/conference-proceedings/. 2020, ISBN: 97880-7454-935-9, pp. 352-364.

26. OECD: Shocks, Risks and Global Value Chains: Insights from the OECD METRO Model. Paris: OECD Publishing, 2020. 27. Schmidt-Traub, G., Hoff, H., Bernlöhr, M.: International spillovers and the Sustainable Development Goals (SDGs): Measuring how a country's progress towards the SDGs is

affected by actions in other countries. Paris: Sustainable Development Solutions Network, SDSN Policy Brief, 2019.

28. SDSN and IEEP: 2019 Europe Sustainable Development Report. Paris and Brussels: Sustainable Development Solutions Network and Institute for European Environmental Policy, 2019. 29. SDSN and IEEP: The 2020 Europe Sustainable Development Report: Meeting the Sustainable Development Goals in the face of the COVID-19 pandemic. Paris and Brussels: Sustainable Development Solutions Network and Institute for European Environmental Policy, 2020.

30. Smith, A.: An Inquiry into the Nature and Causes of the Wealth of Nations. Indianapolis: Liberty Classics, 1776.

31. UNCTAD: UNCTADSTAT. 2021.

https://unctadstat.unctad.org/EN/RcaRadar.htm

32. Vollrath, T. L.: A theoretical evaluation of alternative trade intensity measures of revealed comparative advantage. In: Weltwirtschaftliches Archiv. 1991. 130. pp. 263-279.

33. von der Leyen, U.: A Union that Strives for More: My Agenda for Europe - Political Guidelines for the Next European Commission 2019-2024. Brussels: Publications Office of the European Union, 2019.

34. Wojciechowski, J.: Keynote speech at the 2021 EU Agricultural Outlook Conference. Brussels, 9 December 2021, SPEECH/21/6723.

35. WTO and UN: ITC TradeMap Database. 2021. Retrieved from https://www.trademap.org/Index.aspx

36. Yueh, L.: The Great Economists. London: Penguin Books, 2019.

37. Zábojník, S., Čiderová D., Krajčík D.: Competitiveness in International Business: Challenges for the EU Economies. Praha: Wolters Kluwer Czech Republic, 2020, 272 p. ISBN 978-80-7676-006-6.

38. Zorkóciová, O., Palušková, H.: Environmental Economics Solutions for Plastic Waste Recycling. In Trends and Challenges in the European Business Environment: Trade, International Business and Tourism. International Scientific Conference. Trends and Challenges in the European Business Environment: Trade, International Business and Tourism: Proceedings of the 6th International Scientific Conference, October 17 - 18, 2019
(Mojmírovce, Slovak Republic). Bratislava: Vydavatel'stvo EKONÓM, 2019. ISBN 978-80-225-4646-1, pp. 487-495. 39. Zorkóciová, O., Palušková, H.: Green Roof's Project Environmental Solution for the People and the Company. In Management Mechanisms and Development Strategies of Economic Entities in Conditions of Institutional Transformations of the Global Environment. Scientific Council. Management Mechanisms and Development Strategies of Economic Entities in Conditions of Institutional Transformations of the Global Environment: Collective Monograph in 2 Vol.: Publication at the Meeting of the Scientific Council, 8 January 2019, No. 1-19. Riga: Landmark SIA, 2019. ISBN 978-9984-891-06-4, pp. 59-75 online.

40. Zorkóciová, O., Petríková, H.: Determinants of Increasing the Foreign Direct Investment Inflow Into the Republic of Serbia. In Scientific Council of the Information Systems Management University. Transformation Processes the Development of Economic Systems in Conditions of Globalization: Scientific Bases, Mechanisms, Prospects : Collective Monograph. Riga: ISMA University, 2018. ISBN 978-9984-891-05-7. ISSN 1492-8965, pp. 144-162.

Primary Paper Section: A

Secondary Paper Section: AH, EH 